\title{
RISK EFFECT OF MATERNAL NUTRITION ON BIRTH WEIGHT OF BABY- A PROSPECTIVE STUDY
}

\author{
Anuradha Seedidhi' ${ }^{1}$ Geeta Kumari Ponnada²
}

${ }^{1}$ Associate Professor, Department of Obstetrics and Gynaecology, RIMS Medical College, Ongole.

${ }^{2}$ Assistant Professor, Department of Obstetrics and Gynaecology, Andhra Medical College, Visakhapatnam.

\section{ABSTRACT}

\section{BACKGROUND}

Low birth weight of the baby is associated with increased incidence of neonatal morbidity and mortality. The present study is aimed at assessing the effect of maternal nutritional status during pregnancy on weight of the baby.

\section{MATERIALS AND METHODS}

It is a concurrent cohort study done over a period of one month among 500 antenatal women of 28 weeks of gestation, attending the Department of Obstetrics and Gynaecology, King George Hospital, Visakhapatnam. Nutritional assessment of all antenatal mothers was done by a pretested structured questionnaire. Haemoglobin level was estimated in laboratory. All antenatal women were followed up till term for the outcome, which is birth weight of baby.

\section{RESULTS}

Majority of women (41.2\%) had caloric intake between 1601 and $1800 \mathrm{Kcal}$; $35 \%$ women had protein intake of $51 \%-60 \%$. Haemoglobin level was 7 - 10 gm in 59\% of women; $48.48 \%$ of women taking daily calorie intake of $<1400$ kcal delivered babies with weight $<2000 \mathrm{gm} ; 54.54 \%$ of women with protein intake $<50$ gms per day delivered babies with weight $<2000$ gms; $57.57 \%$ women with $\mathrm{Hb}$ level $<7$ gms\% delivered babies with weight $<2000$ gms, whereas mothers with Hb level $>10$ gms $\%$ delivered babies with weight $>3000$ gms.

\section{CONCLUSION}

Maternal nutrition has impact on newborn birth weight.

\section{KEYWORDS}

Maternal Nutrition, Baby Weight, Pregnancy, Calorie, Haemoglobin.

HOW TO CITE THIS ARTICLE: Seedidhi A, Ponnada GK. Risk effect of maternal nutrition on birth weight of baby- a prospective study. J. Evolution Med. Dent. Sci. 2017;6(76):5431-5434, DOI: 10.14260/Jemds/2017/1178

\begin{abstract}
BACKGROUND
Mother and child are considered as a single entity socially, culturally and biologically. The biological support which a child receives from its mother during the course of its development and growth, through pregnancy and lactation depends on the kind of nourishment a mother receives during her pregnancy.(1) In developing countries like India, health status of mother in reproductive age group decides the health of the society that finally determines the health of the community.(1) Low birth weight (LBW) infants (Birth weight $<2500 \mathrm{gms}$ ) are at risk of neonatal morbidity and mortality. Infant weight is directly linked to maternal nutritional status. Lower calorie and protein intake by mother during pregnancy can result in small size of baby.(2) The present study was done to assess the relation between the calorie intake, protein intake and haemoglobin level of mother during her pregnancy with birth weight of baby.
\end{abstract}

\section{MATERIALS AND METHODS}

The present concurrent cohort study was conducted among 500 pregnant women selected by convenient sampling who

Financial or Other, Competing Interest: None.

Submission 25-05-2017, Peer Review 09-09-2017,

Acceptance 15-09-2017, Published 21-09-2017.

Corresponding Author:

Dr. Anuradha Seedidhi,

\#14-10-63/6, Flat-6,

Sarojini Courts, Ramjogipeta,

Visakhapatnam-530002.

E-mail: drsanuradha9@yahoo.co.in

DOI: $10.14260 /$ jemds $/ 2017 / 1178$ were antenatal women of 28 wks. of gestation who attended the antenatal clinic in the Department of Obstetrics and Gynaecology, KGH, Visakhapatnam during the period of December 2016.

A detailed personal history including last menstrual period, immunisation status, previous medical and obstetric history and interval between last births was taken. A detailed dietary history by 24-hour recall method was obtained by interview technique on a prelisted proforma. Protein and calorie intake of cooked food of each case was estimated by simple household measures like bowl/katori, cup and spoon. In laboratory investigations Haemoglobin estimation was done using standard Sahli's method, urinalysis were done in microbiology laboratory for every case. Blood sugar, serum creatinine, thyroid function tests were done to exclude medical disorders. Anaemia was classified as per WHO standards as mild (10 - 11 gms\%), moderate (7 - 10 gms\%) and severe anaemia $(<7 \mathrm{gms} \%)$. After registration at 28 weeks gestation antenatal followup was carried every two weeks, i.e. at 30, 32, 34, 36, 38 and 40 weeks of gestation. At each visit, mother's weight and blood pressure were recorded. The average of the readings obtained from each visit is considered for final analysis. All cases were well followed up till delivery. All deliveries were institutional. Weight of all babies was recorded immediately after birth using the electronic weighing machine by attending staff member. 


\section{Exclusion Criteria}

Pregnant women with preeclampsia toxaemia, diabetes mellitus and women who were at risk for gestational diabetes mellitus were excluded. Women with renal problems and all pregnant women with any systemic or metabolic disorders were excluded.

Analysis was done and the result is described as percentages and the relative risk is calculated. Data was entered in Microsoft Excel and analysed in SPSS v.23 software.

Ethical clearance was obtained from the Institutional Ethical Committee.

\section{RESULTS}

In the present study, most women (385 out of $500,77 \%$ ) belonged to age group 18 - 25 years and 125 women (23\%) in 26 - 30 years' age group. When literacy was taken into consideration 325 out of 500 (65\%) were found illiterate, only $35 \%$ (175) were having basic education; $38 \%$ belonged to socioeconomic class II and $92.5 \%$ were housewives.

Analysis of results according to parity revealed that majority of women, i.e. 376 out of 500 women $(75.2 \%)$ were primigravidae and 124 out of 500 women (24.8\%) were multigravidae (Gravida 2 or more). Most of the primis 298 out of $376(79.25 \%)$ primi and 106 out of 124 (85.48\%) multigravida belonged to 18 - 25 years' age group.

$79.2 \%$ of women (396 out of 500 ) gained weight of more than $4 \mathrm{~kg}$ during their pregnancy, whereas $20.8 \%$ of women (104 out of 500) gained weight of 3100 gms to 4000 gms.

Most women (58.55\%) were of average height measuring between 151 and $158 \mathrm{~cm}$, whereas 26.11\% women were between 146 - $158 \mathrm{~cm}$ height and 15.34\% were less than 145 $\mathrm{cm}$.

When foetal parameters were taken into consideration 336 out of 500 foetuses (67.2\%) weighed between 2100 gms
- 2500 gms; 123 out of 500 foetuses weighed 2600 gms 3000 gms amounting to $24.6 \%$; 33 foetuses out of 500 (6.6\%) weighed less than 2000 gms; 8 foetuses out of 500 (1.6\%) weighed more than 3000 gms. Majority of foetuses weighed between 2100 gms - 2500 gms accounting to $67.2 \%$.

$36.33 \%$ of women had inter-pregnancy interval of more than 18 months and $63.67 \%$ of women had an interpregnancy interval of less than 18 months showing that majority of study population had frequent childbirths.

396 out of 500 women $(79.2 \%)$ had spontaneous vaginal delivery. Rest 104 women delivered by operative delivery $(20.8 \%)$, indications varied from very low birth weight to obstetric indications.

Analysis of daily calorie intake by the pregnant women has shown that 206 women out of 500 women (41.2\%) reported a calorie intake between $1601-1800 \mathrm{kcal} ; 40.4 \%$ of women (202 women out of 500) were reported to have a daily calorie intake of 1401 - $1600 \mathrm{kcal}$.

Analysis of daily protein intake by the pregnant women has shown that 109 out of 500 women (21.8\%) had protein intake of more than 70 gms followed by 177 women out of 500 women (35.4\%) had protein intake between 61 - $70 \mathrm{gms}$ and 175 women out of 500 women (35\%) had a daily protein intake of 51 - 60 gms. This has shown that very less number of women had received daily protein intake of more than 70 gms.

When haematocrit of the pregnant women was analysed, 297 women out of 500 women (59\%) were found to have haemogram between 7 - $10 \mathrm{gm} \%$, while 157 women out of 500 women have shown a haemoglobin between $10-11$ gm\% amounting to $31.4 \%$ of the total only 48 women $(9.6 \%)$ were found to be severely anaemic with haemoglobin of less than $7 \mathrm{gm} \%$.

\begin{tabular}{|c|c|c|c|c|c|}
\hline \multirow{2}{*}{\multicolumn{2}{|c|}{ Maternal Parameters }} & \multicolumn{4}{|c|}{ Baby Weight in Grams } \\
\hline & & $\begin{array}{l}<2000 \\
(n=33)\end{array}$ & $\begin{array}{c}2100-2500 \\
(n=336)\end{array}$ & $\begin{array}{c}2600-3000 \\
(n=123)\end{array}$ & $\begin{array}{l}>3000 \\
(n=8)\end{array}$ \\
\hline \multirow{4}{*}{$\begin{array}{c}\text { Calorie } \\
\text { Intake } \\
\text { (kcal) }\end{array}$} & $<1400$ & $16(48.48 \%)$ & $\begin{array}{c}0 \\
(0 \%) \\
\end{array}$ & $0(0 \%)$ & $\begin{array}{c}0 \\
(0 \%)\end{array}$ \\
\hline & $1401-1600$ & $14(42.42 \%)$ & $172(51.19 \%)$ & $\begin{array}{c}16 \\
(13.00 \%)\end{array}$ & $\begin{array}{c}0 \\
(0 \%)\end{array}$ \\
\hline & $1600-1800$ & $\begin{array}{c}3 \\
(9.09 \%) \\
\end{array}$ & $148(44.04 \%)$ & $\begin{array}{c}42 \\
(34.14 \%) \\
\end{array}$ & $\begin{array}{c}2 \\
(25 \%) \\
\end{array}$ \\
\hline & $>1800$ & $0(0 \%)$ & $\begin{array}{c}16 \\
(4.76 \%) \\
\end{array}$ & $\begin{array}{c}65 \\
(52.84 \%) \\
\end{array}$ & $\begin{array}{c}6 \\
(75 \%) \\
\end{array}$ \\
\hline \multirow{4}{*}{$\begin{array}{c}\text { Protein } \\
\text { Intake } \\
\text { (Gms) }\end{array}$} & $<50$ & $18(54.54 \%)$ & $\begin{array}{c}16 \\
(4.76 \%) \\
\end{array}$ & $\begin{array}{c}5 \\
(4.06 \%) \\
\end{array}$ & $\begin{array}{c}0 \\
(0 \%) \\
\end{array}$ \\
\hline & $51-60$ & $\begin{array}{c}9 \\
(27.27 \%) \\
\end{array}$ & 147 (43.75\%) & $\begin{array}{c}18 \\
(14.63 \%) \\
\end{array}$ & $\begin{array}{c}1 \\
(12.5 \%) \\
\end{array}$ \\
\hline & $61-70$ & $\begin{array}{c}4 \\
(12.12 \%) \\
\end{array}$ & $139(41.36 \%)$ & $\begin{array}{c}32 \\
(26.01 \%) \\
\end{array}$ & $\begin{array}{c}2 \\
(25 \%) \\
\end{array}$ \\
\hline & $>70$ & $\begin{array}{c}2 \\
(6.06 \%)\end{array}$ & $\begin{array}{c}34 \\
(10.11 \%)\end{array}$ & $\begin{array}{c}68 \\
(55.28 \%)\end{array}$ & $\begin{array}{c}5 \\
(62.5 \%)\end{array}$ \\
\hline \multirow{3}{*}{$\begin{array}{c}\text { Hb } \\
\text { (gms } \\
\% \text { ) }\end{array}$} & $<7$ & $19(57.57 \%)$ & $\begin{array}{c}24 \\
(7.14 \%) \\
\end{array}$ & $\begin{array}{c}5 \\
(4.06 \%) \\
\end{array}$ & $\begin{array}{c}0 \\
(0 \%) \\
\end{array}$ \\
\hline & $07-10$ & $\begin{array}{c}9 \\
(27.27 \%)\end{array}$ & $228(67.85 \%)$ & $\begin{array}{c}56 \\
(45.52 \%)\end{array}$ & $\begin{array}{c}2 \\
(25 \%)\end{array}$ \\
\hline & $10-11$ & $\begin{array}{c}5 \\
(15.15 \%)\end{array}$ & $\begin{array}{c}84 \\
(25 \%) \\
\end{array}$ & $\begin{array}{c}62 \\
(50.40 \%) \\
\end{array}$ & $\begin{array}{c}6 \\
(75 \%) \\
\end{array}$ \\
\hline \multicolumn{6}{|c|}{ Table 1. Distribution of different Parameters of Mother and Correlation with Baby Weight } \\
\hline
\end{tabular}




\begin{tabular}{|c|c|c|c|c|c|c|c|}
\hline \multirow{2}{*}{\multicolumn{2}{|c|}{ Maternal Parameters }} & \multicolumn{2}{|c|}{ Baby Status } & \multirow{2}{*}{ Total } & \multirow{2}{*}{$\begin{array}{c}\text { Relative } \\
\text { Risk }\end{array}$} & \multirow{2}{*}{$\begin{array}{l}\text { Pearson } \\
\text { Chi-Square }\end{array}$} & \multirow{2}{*}{$\begin{array}{c}P \\
\text { Value }\end{array}$} \\
\hline & & Low Birth Wgt. & Normal Weight & & & & \\
\hline \multirow{3}{*}{$\begin{array}{l}\text { Calorie } \\
\text { Intake }\end{array}$} & Upto 1600 & $202(0.547 \%)$ & $16(12.20 \%)$ & $218(43.60 \%)$ & 4.48 & 71.11 & $<0.05$ \\
\hline & $>1600$ & $167(45.30 \%)$ & $115(87.80 \%)$ & $282(56.40 \%)$ & & & \\
\hline & Total & 369 & 131 & 500 & & & \\
\hline \multirow{3}{*}{$\begin{array}{l}\text { Protein } \\
\text { Intake }\end{array}$} & upto 60 & $190(51.50 \%)$ & $24(18.30 \%)$ & $214(42.80 \%)$ & 2.81 & 43.449 & $<0.05$ \\
\hline & $>60$ & $179(48.50 \%)$ & $107(81.70 \%)$ & $286(57.20 \%)$ & & & \\
\hline & Total & 369 & 131 & 500 & & & \\
\hline \multirow{3}{*}{ Hb Status } & Anaemia (upto 10) & $280(75.9 \%)$ & $63(48.1 \%)$ & $343(68.6 \%)$ & 1.57 & 34.66 & $<0.05$ \\
\hline & Normal (>11) & $89(24.1 \%)$ & $68(51.9 \%)$ & $157(31.4 \%)$ & & & \\
\hline & Total & 369 & 131 & 500 & & & \\
\hline
\end{tabular}

\section{DISCUSSION}

Low birth weight is associated with increased risk of newborn morbidity and mortality.(3) Women who is wellnourished during her pregnancy can fulfil the demand of growing foetus. Well-nourished foetus will result in a healthy baby with optimum body weight. Hence, it is essential that mother's diet must contain adequate nutrients during her pregnancy, so that chances of low birth weight baby can be avoided.(4) Present study depicts current nutritional status of women as indicated by calorie intake is directly related to birth weight of the baby. Total calorie intake between 1601 $1800 \mathrm{kcal}$ was recorded in $41.2 \%$ women, while $40 \%$ and $17 \%$ had daily calorie intake between $1401-1600 \mathrm{kcal}$ and $>1800 \mathrm{kcal}$ respectively. When caloric intake of mother was correlated with baby weight, it was found that more than half of patients who were taking calories between $1401-1600$ delivered baby with body weight $<2000$ gms. While those who were taking $>1800 \mathrm{kcal}$ per day delivered baby with weight $>3000$ gms.

Study done by Raman et al reported that inadequate caloric intake can result in LBW babies and even supplementation given for anaemic correction would not be able to increase the birth weight,(5) whereas study done by Kennedy et al found that birth weight of baby can be improved with the help of supplementation.(6) In present study $35 \%$ were consuming 51 - 60 gms of protein daily, while $21 \%$ had above 70 gms of protein intake. About $48.5 \%$ women with total intake above $70 \mathrm{gms}$ had baby weight < 2000 gms, while $37.5 \%$ had baby weight above 3000 gms within same group.

Raman et al reported a decrease in abortions, preterm deliveries and still births with increasing dietary protein. Raman et al also reported that protein consumption in the range of $30 \%-50 \%$ of total diet would reduce chances of LBW babies.(5) Dickman et al reported a reduction in $\mathrm{Hb}$ level by $20 \%$ between 16 th and 35 th week of pregnancy.(7) Severe anaemia can lead to lower birth weight.(3) In present study $59 \%$ of women has $\mathrm{Hb}$ between $7-10$ gms $\%$, while $9.6 \%$ were severe anaemic with $\mathrm{Hb}<7$ gms\%. Most of the patients (57.57\%) with $\mathrm{Hb}<7 \mathrm{gms} \%$ had baby weight $<2000 \mathrm{gms}$, whereas babies with weight above 3000 gms were delivered by patient with $\mathrm{Hb}>10$ gms\%. Amosu et al did a study on 512 women and reported that mother with $\mathrm{Hb}$ level $<7$ gms $\%$ found to have $9.96 \%$ incidence of LBW, whereas incidence of LBW was only in $0.59 \%$ with mother having $\mathrm{Hb}$ level of $>10$ gms\%. Gogoi et al in their study observed that $50 \%-60 \%$ women had nutritional anaemia in later months of pregnancy. Studies have recommended an $\mathrm{Hb}$ level of normal women should be around $80 \%$ in order to avoid complication.(1) Giles et al reported a progressive fall of $\mathrm{Hb}$ level during the course of pregnancy. The magnitude of fall was influenced by age and parity to a lesser extent.(8) Gargi et al in their study involving 1233 antenatal women of 28 weeks of gestation did not find any significant relation of baby weight with calorie intake. The reason for non-significant relation was not explained by the author. The present study has observed a direct relation between protein intake and baby weight, but with protein intake more than 70 gms daily has not shown any further significant increase in baby weight rather it resulted in baby weight reduction. Rush et al did a similar study and reported that high protein intake might reduce the baby weight. ${ }^{(9)}$

\section{CONCLUSION}

Counselling on appropriate weight gain in pregnancy during antenatal clinics and optimum nutrition before pregnancy for prospective mothers is emphasised. Discussions about weight are important, since approximately half of the mothers in their study with poor nutritional status have delivered low birth weight babies. Reports have shown that severe anaemia can lead to low birth weight. In Asian countries like India, pregnancy-induced anaemia is a common complication.

The present study concludes that the nutritional status of mother can significantly influence the weight of the newborn baby. Poorly nourished mothers were found to deliver LBW babies as compared to well-nourished women.

\section{REFERENCES}

[1] Gogoi G, Ahmed FU. Effect of maternal nutritional status on the birth weight among women of tea tribe in Dibrugash district. Indian J Community Medicine 2007;32(2):120-2.

[2] Thame M, Wilks RJ, McFarlane-Anderson $\mathrm{N}$, et al. Relationship between maternal nutritional status and infant's weight and body proportions at birth. Eur J Clin Nutr 1997;51(3):134-8.

[3] Amosu AM, Degun AM. Impact of maternal nutrition on birth weight of babies. Biomedical Research 2014;25(1):75-8.

[4] Sharma M, Mishra S. Effect of maternal health and nutrition on birth weight of infant. International Journal of Science and Research 2014;3:855-8.

[5] Raman L. Influence of maternal nutritional factors affecting birthweight. Am J Clin Nutr 1981;34(Suppl 4):775-83.

[6] Kennedy ET, Gershoff S, Reed R, et al. Evaluation of the effect of WIC supplemental feeding on birth weight. J Am Diet Assoc 1982;80(3):220-7. 


\section{Jemds.com}

[7] Dickmann WJ, Wagner CR. Arch Ind Med 1934:53(71). Quoted from Gupta D 1954.

[8] Giles C, Burton H. Observation on prevention and diagnose of anaemia in pregnancy. $\mathrm{Br}$ Med $\mathrm{J}$ 1960;2(5199):636-40.

\section{Original Research Article}

[9] Rush D. Effects of changes and calorie intake during pregnancy on the growth of the human fetus. In: Effectiveness and Satisfaction in Antenatal Care. Clinics in Developmental Medicine Series. Eds. M Enkin, I Chalmers. London: Spastics International Medical Publications, 1982:pp. 92-113. 